\title{
Electrocardiographic Changes in Dengue Fever: A Review of Literature
}

\author{
Ashwin Parchani (iD) \\ Gokul Krishnan VS (D) ${ }^{2}$ \\ VK Sunil Kumar iD ${ }^{3}$ \\ 'Department of Internal Medicine, All \\ India Institute of Medical Sciences, \\ Rishikesh, 249203, India; ${ }^{2}$ Department of \\ Internal Medicine, Kasturba Medical \\ College, Manipal, 576I04, India; \\ ${ }^{3}$ Consultant Cardiologist, $V$ Care \\ Polyclinic, Dubai, United Arab Emirates
}

\begin{abstract}
Dengue fever is a prevalent viral disease that primarily affects tropical nations. Although most symptomatic infections have a relatively benign course, a small percentage of patients experience severe clinical symptoms, such as bleeding and endothelial dysfunction, which can lead to hypovolemic shock and cardiovascular collapse. Dengue fever is now known to involve the heart by inducing myocardial inflammation, arrhythmias, and, in rare cases, fulminant myocarditis, up to $13 \%$ in severe dengue. Conduction abnormalities can range from benign sinus bradycardia to fulminant tachyarrhythmias and atrioventricular blocks. Although most conduction disturbances are benign and transient, they can occasionally aggravate pre-existing conditions and even be fatal. Unlike other viral myocarditis like hepatitis $\mathrm{C}$ induced myocarditis, dengue causes mainly transient changes, and long-term complications like dilated cardiomyopathy are not noted. There is indeed a paucity of data on how to assess and treat individuals with conduction abnormalities. In this review, the authors have discussed the wide variety of conduction abnormalities seen in dengue, their pathophysiology, clinical consequences, and a method for evaluating and managing these individuals.
\end{abstract}

Keywords: Dengue fever, Electrocardiography, Arrhythmia, Myocarditis

\section{Introduction}

Dengue fever is among the world's most severe emerging viral diseases. ${ }^{2}$ In recent years, the prevalence of dengue virus (DENV) infection has been on the rise. The vast majority of symptomatic infections have a benign clinical trajectory. Some patients experience severe clinical manifestations such as bleeding, organ failure, and endothelial dysfunction with elevated capillary permeability, resulting in hypovolemic shock and cardiovascular failure. Electrocardiography (ECG) and echocardiography abnormalities are common during dengue infection. ${ }^{3,4}$ Due to the low clinical suspicion index and simultaneous clinical symptoms, including hypotension, tachycardia, pulmonary edema, and capillary leak related with DENV infection, cardiac activity in dengue fever is often underdiagnosed. Clinically evident heart disease is of low prevalence in any individual care facility, but it accounts for a significant percentage of seriously ill patients in the aggregate. Although most patients are asymptomatic or transient, life-threatening cardiac involvement is frequent in dengue hemorrhagic fever and dengue shock syndrome. These cardiac complications might be overlooked in clinical practice and can contribute to the mortality observed in dengue.

\section{Dengue Virus}

DENV is a single-stranded ribonucleic acid (RNA) virus that exists as four distinct serotypes (DENV-1 to -4$).^{5}$ These DENV serotypes are members of the Flavivirus 
genus and family Flaviviridae. ${ }^{6}$ The mature particle of DENV is spherical in shape with a diameter of $50 \mathrm{~nm}$ and contain several copies of the three structural proteins, a hostderived membrane bilayer, and a single positive-sense, single-stranded RNA genome. The genome is cleaved by host and viral proteases in three structural proteins (capsid, C, prM, the precursor of membrane, M, protein and envelope, E) and seven non-structural proteins (NS). ${ }^{7}$

\section{Cardiac Involvement in Dengue Pathophysiology}

The pathophysiology of cardiac disease in dengue infection is unclear. A variety of factors contribute to its pathogenesis, which results in myocardial injury and subsequent conduction abnormalities (Figure 1). Direct viral invasion of cardiac muscles, cytokine-induced immunological injury, or both can cause cardiac involvement. ${ }^{8,9}$ Electrolyte imbalance, calcium homeostasis disruption, lactic acidosis, and ischemia due to hypotension are all thought to play a role in the myocardial dysfunction seen in dengue patients. Increased levels of proinflammatory cytokines, vasoactive mediators, and cytotoxic factors in dengue patients can increase vascular permeability and result in shock. ${ }^{10,11}$ These can further impede coronary blood supply, resulting in a cascade of ischemia and subsequent electrophysiological changes. Pericardial effusion is caused by increased vascular permeability and abnormal plasma leakage. ${ }^{12}$ It is unclear whether the myocyte injury is caused by a direct invasion of the DENV virus or by an immune-mediated mechanism. On cardiac specimens from dengue patients, viral antigens such as dengue capsid protein, non-structural protein 1 (NS1), and viral RNA were identified using reverse transcription polymerase chain reaction. ${ }^{13,14}$ Immunohistochemistry has also revealed dengue capsid protein in several cardiac cell types, including cardiomyocytes, myocardial interstitial cells, and myoblasts. ${ }^{15}$ Autopsy specimens have also revealed interstitial oedema, inflammation, and myocardial fibre necrosis. ${ }^{1}$

Arrhythmias are of fairly common occurrence in dengue infection, and multiple factors are predicted to interplay in its pathogenesis. ${ }^{3,4,16}$ Firstly, changes in membrane potential can occur as a result of inflammatory processes and cytokine storms affecting myocytes and the interstitium. ${ }^{17}$ Arrhythmias can also be triggered by changes in ventricular dynamics, such as increased wall strain and myocardial oxygen demand. Moreover, there is a risk of bleeding in or around the sinoatrial or atrioventricular node due to low platelet counts, which can cause conduction defects and arrhythmias. ${ }^{18}$ Changes in autonomic tone and electrolyte imbalances might cause transient rhythm abnormalities.

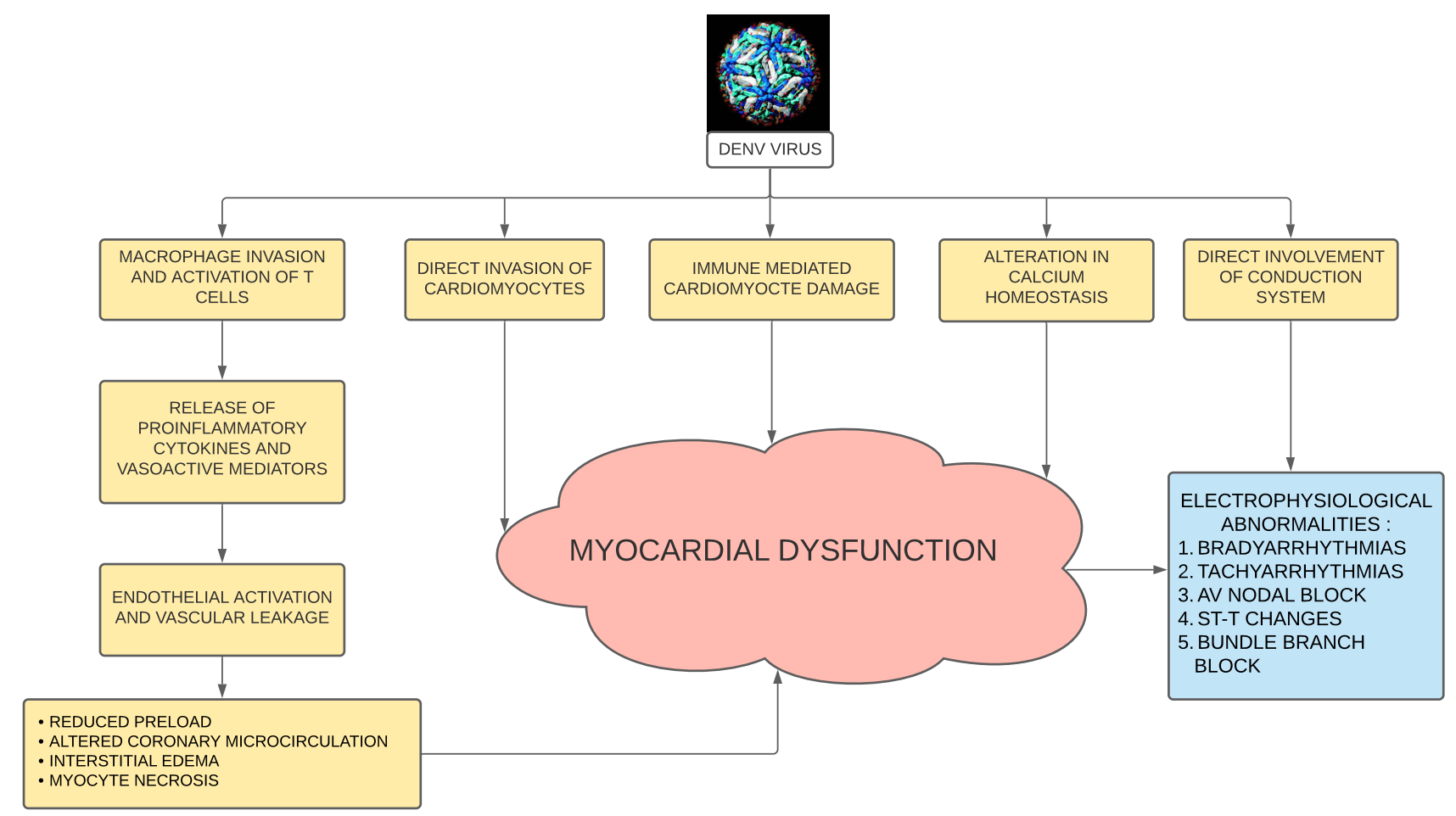

Figure I Proposed pathogenesis of conduction abnormalities in dengue fever. 


\section{Electrocardiographic Changes}

In individuals with dengue infection, studies have shown a number of ECG abnormalities (Table 1). Based on the findings depicted in Table 1, electrical disturbances noted in dengue can be broadly categorized into bradyarrhythmias and tachyarrhythmias.

\section{Following Classification is Proposed}

- Bradyarrhythmia

- Sinus bradycardia

- Junctional rhythm

○ AV block

- First degree

- Second degree

- Third degree

- Bundle branch block

- Tachyarrhythmia

- Supraventricular

- Ventricular

- Nonspecific ST-T changes

\section{Bradyarrhythmia}

Bradycardia is the most common electrical disturbance seen in dengue. Sinus bradycardia is the most common cause of bradycardia and is usually benign. Relative bradycardia is also noted where dengue cases had a reduced heart rate response than other febrile illnesses. Junctional rhythms have also been reported in literature. ${ }^{3}$ Atrial and ventricular ectopics are seen often in dengue and are usually benign. ${ }^{3}$ There have been reports of a high degree AV block leading to ventricular asystole, which was managed medically with intravenous atropine and orciprenaline. Conduction blocks are more life-threatening conditions ranging from 1st degree AV block to complete heart block. Generally higher the degree of the block, more remarkable is the incidence of complications like asystole, ventricular arrhythmias, hemodynamic compromise and requirement of more aggressive and invasive interventions in the form of pharmacotherapy, pacing and ICU admission. ${ }^{19}$

\section{Tachyarrhythmia}

Among the tachyarrhythmias seen in dengue, the most common is sinus tachycardia. Others include supraventricular arrhythmias like atrial fibrillation and rarely ventricular tachycardias. ${ }^{4}$ They can be managed conservatively, and resolution of underlying myocarditis and volume loss resolves the tachycardia.

\section{ST-T Changes}

ST-T changes on ECG in dengue are usually secondary to myocarditis or pericarditis and not primary electrical disturbance, unlike sinus bradycardia and heart blocks, which can occur even in the absence of myocarditis. ${ }^{20}$

\section{Clinical Implications}

Arrhythmias seen in dengue are primarily benign, transient and self-limiting. However, they can range from mild symptoms to significant contributions to morbidity and mortality in specific subsets. Conduction blocks can aggravate existing cardiovascular compromise secondary to capillary leak and third space loss. Severe bradycardia can result in worsening of hypotension and symptoms varying from presyncope to cardiac arrest. In dengue, the heart is unable to mount a sufficient chronotropic response to compensate for the hypotension.

The contribution of rhythm disturbances to mortality is not clearly defined. According to one study, all the patients who died exhibited aberrant echocardiography or ECG results. ${ }^{27}$ During an outbreak in Sri Lanka, a study revealed that those with bradyarrhythmia were more likely to develop hypotension. ${ }^{26}$ In addition to mortality, electrical abnormalities contribute significantly to morbidity in the form that they require further evaluation, interventions and complications of clinical course. Conduction disturbances are often seen towards the recovery phase of dengue when the patient is improving from other dengue-related complications like thrombocytopenia, serositis, and hypotension. The newly appearing conduction disturbances can prolong hospital stay, ICU admission, further investigations and interventions. Investigations performed are in the form of holter monitoring, cardiac enzymes and repeat echocardiography. Although the electrical abnormalities usually resolve in three weeks, conduction defects have persisted in specific individuals, and cases are reported where it took up to five months for recovery. ${ }^{28}$ Those with symptomatic heart blocks have had to undergo pacing or pharmacotherapy. Unnecessary interventions, on the other hand, for relatively benign transient rhythm disturbances add to the burden. A challenge faced is in performing pacing among those with severe thrombocytopenia and active bleeding. There have been reported instances where pacing had to be deferred due to severe thrombocytopenia.

Some studies indicate no relationship between the clinical severity of dengue and incidence of cardiac arrhythmia, suggesting that monitoring for cardiac arrhythmias 
Table I Studies of Conduction Abnormalities in Dengue Fever

\begin{tabular}{|c|c|c|c|c|}
\hline Reference & Study Setting & $\mathbf{n}$ & Country & Electrocardiographic Manifestations \\
\hline $\begin{array}{l}\text { Krishna } \\
\text { et al }{ }^{16}(2021)\end{array}$ & $\begin{array}{l}\text { Hospitalized patients, Adults and } \\
\text { older children }\end{array}$ & 108 & INDIA & $\begin{array}{l}\text { Abnormal ECG in } 48.14 \% \text { patients } \\
\text { Sinus bradycardia }-31.48 \% \\
\text { ST-T changes - } 11.1 \% \\
\text { Sinus tachycardia }-3.7 \% \\
\text { RBBB - } 1.85 \%\end{array}$ \\
\hline $\begin{array}{l}\text { Shah et } \mathrm{al}^{4} \\
(202 \mathrm{I})\end{array}$ & $\begin{array}{l}\text { Hospitalized patients, Adults above } \\
\text { age of } 18 \text { years }\end{array}$ & 320 & INDIA & $\begin{array}{l}\text { ECG abnormalities noted in } 35 \% \text { subjects. } \\
\text { Sinus bradycardia }-19.7 \% \\
\text { Sinus Tachycardia }-6.9 \% \\
\text { Ist Degree AV Block }-1.9 \% \\
\text { 2nd Degree AV Block }-0.3 \% \\
\text { Complete Heart Block }-0.6 \% \\
\text { Atrial fibrillation }-3.75 \% \\
\text { ST elevation - } 1.2 \% \\
\text { Ventricular tachycardia }-1.8 \%\end{array}$ \\
\hline $\begin{array}{l}\text { Papalkar } \\
\text { et al }{ }^{21}(2019)\end{array}$ & $\begin{array}{l}\text { Hospitalized patients, Adults and } \\
\text { older children }\end{array}$ & 60 & INDIA & $\begin{array}{l}\text { ECG abnormality noted in } 35 \% \text { patients } \\
\text { Sinus bradycardia }-15 \% \\
\text { Sinus tachycardia }-10 \% \\
\text { ST-T changes }-8.33 \% \\
\text { PR prolongation }-1.67 \%\end{array}$ \\
\hline $\begin{array}{l}\text { Poornima } \\
\text { and John } \\
(2019)\end{array}$ & $\begin{array}{l}\text { Hospitalized patients, Adults and } \\
\text { children }\end{array}$ & 341 & INDIA & $\begin{array}{l}\text { Abnormal ECG changes noted in } 72 \text { patients }(21.11 \%) \\
\text { Sinus bradycardia }-8.79 \% \\
\text { T wave inversion }-4.1 \% \\
\text { ST depression }-2.3 \% \\
\text { AV block }-2.34 \% \\
\text { Atrial fibrillation }-2.93 \% \\
\text { Junctional rhythm }-1.15 \% \\
\text { Supraventricular tachycardia }-0.58 \% \\
\text { Ventricular ectopics }-1.75 \%\end{array}$ \\
\hline $\begin{array}{l}\text { Datta and } \\
\text { Mitra }^{22} \\
(2019)\end{array}$ & $\begin{array}{l}\text { Hospitalized patients, Adults and } \\
\text { older children }\end{array}$ & 110 & INDIA & $\begin{array}{l}\text { ECG abnormality noted in } 8.2 \% \text { patients } \\
\text { Sinus bradycardia }-3.7 \% \\
\text { Junctional bradycardia }-2.7 \% \\
\text { AV block }-0.9 \% \\
\text { Atrial fibrillation }-0.9 \%\end{array}$ \\
\hline $\begin{array}{l}\text { Kumar and } \\
\text { Yadav }^{23} \\
(2017)\end{array}$ & Hospitalized patients, Adults & 100 & INDIA & $\begin{array}{l}\text { ECG abnormalities noted in } 87 \% \text { subjects } \\
\text { Sinus bradycardia }-60 \% \\
\text { Sinus tachycardia }-27 \% \\
\text { Ventricular ectopics - } 15 \% \\
\text { Ist degree AV Block - } 11 \%\end{array}$ \\
\hline $\begin{array}{l}\text { Arora and } \\
\text { Patil }^{24} \\
(2016)\end{array}$ & Hospitalized patients & 120 & INDIA & $\begin{array}{l}\text { ECG abnormalities seen in } 20 \% \text { patients } \\
\text { Sinus bradycardia }-8.3 \% \\
\text { Sinus tachycardia }-3.3 \% \\
\text { ST-T changes }-3.3 \% \\
\text { Ist Degree AV block }-3.3 \% \\
\text { Right bundle branch block }-1.6 \%\end{array}$ \\
\hline $\begin{array}{l}\text { Yacoub } \\
\text { et } \mathrm{al}^{25}(2012)\end{array}$ & $\begin{array}{l}\text { Hospitalized patients, Adults and } \\
\text { children }\end{array}$ & 79 & VIETNAM & $\begin{array}{l}\text { ECG abnormalities noted in } 35 \% \text { subjects including Ist degree AV } \\
\text { block, sinus bradycardia, T wave changes and ST segment } \\
\text { abnormalities }\end{array}$ \\
\hline
\end{tabular}

(Continued) 
Table I (Continued).

\begin{tabular}{|c|c|c|c|c|}
\hline Reference & Study Setting & $\mathbf{n}$ & Country & Electrocardiographic Manifestations \\
\hline $\begin{array}{l}\text { La-Orkhun } \\
\text { et } \mathrm{al}^{26}(20 \mathrm{II})\end{array}$ & $\begin{array}{l}\text { Hospitalized children, During } \\
\text { convalescent phase of dengue } \\
\text { infection }\end{array}$ & 35 & THAILAND & $\begin{array}{l}\text { ECG abnormalities noted in } 29 \% \text { patients } \\
\text { Sinus Pause }-2.9 \% \\
\text { PVC - } 14.3 \% \\
\text { PAC - II.4\% } \\
\text { Ist Degree AV Block }-5.7 \% \\
\text { 2nd Degree AV Block }-8.6 \%\end{array}$ \\
\hline $\begin{array}{l}\text { Kularatne } \\
\text { et } \mathrm{al}^{27}(2007)\end{array}$ & $\begin{array}{l}\text { Hospitalized patients, Adults and } \\
\text { children }\end{array}$ & 120 & SRI LANKA & $\begin{array}{l}\text { ECG changes noted in } 62.5 \% \text { patients including sinus bradycardia, } \\
\text { sinus tachycardia, T wave inversions, ST-segment changes and Right } \\
\text { bundle branch block }\end{array}$ \\
\hline $\begin{array}{l}\text { Wali et al }{ }^{20} \\
(1998)\end{array}$ & $\begin{array}{l}\text { Hospitalized patients, Adults and } \\
\text { children }\end{array}$ & 17 & INDIA & $\begin{array}{l}\text { ECG changes noted in } 47 \% \text { patients } \\
\text { Sinus bradycardia }-17.6 \% \text { patients } \\
\text { ST-T changes }-29.4 \%\end{array}$ \\
\hline
\end{tabular}

may be required even in mild cases. ${ }^{21,29}$ On the other hand, Kumar and Yadav et al have found a statistically significant relation between ECG abnormalities and warning signs suggesting closer follow-up for severe cases. ${ }^{23}$

The absence of infrastructure for such interventions and financial constraints adds to the disease burden in lowincome countries. Procedure-related complications also add to a complicated hospital stay and the total cost of healthcare.

\section{Evaluation and Management}

There are three critical aspects to managing electrophysiological abnormalities in dengue: monitoring, treatment, and decision regarding discharge (Figure 2). For mild cases, we suggest a minimum of two ECGs - one at the time of admission and another before discharge. The purpose of an ECG at admission is to search for conduction disturbances and determine whether additional monitoring is needed. Because it is known that new-onset conduction anomalies might emerge during the recovery period, an ECG should be performed before discharge. Continuous monitoring is recommended in difficult situations, in addition to the two ECGs. In a high dependency unit or ICU environment, continuous monitoring can be done via a monitor. If a monitor is not available, a bare minimum pulse rate and rhythm check twice or three times daily for one minute each would suffice.

Since the majority of bradyarrhythmias are benign and ephemeral, treatment is usually conservative. Pharmacotherapy with atropine and orciprenaline has been used in such circumstances but is of unproven benefit. When there is a worsening conduction block, pacing should be explored. Invasive interventions such as pacing can cause thrombocytopenia and bleeding, which may demand platelet transfusion before the surgery. For severe cases, closer monitoring is warranted. They may be taken up for pacing in a case of bradyarrhythmia in the following conditions:

- Hypotension not responsive to aggressive hydration.

- Worsening trend of bradycardia (sinus bradycardia degenerating to a first degree followed by seconddegree heart block). Such cases might be at imminent risk of complete heart block, asystole or other fatal arrhythmias.

Management of myocarditis is a crucial point as it is responsible for conduction disturbance in several cases. It is usually managed conservatively, but there have been studies exploring the role of steroids, intravenous immunoglobulin (IVIg) and anti-CD3 monoclonal antibody (muromonab) for earlier recovery. ST-T changes seen in dengue are almost always benign, transient and secondary to myocarditis, not requiring specific intervention. ${ }^{30}$

Decision on discharge is to be taken based on ECG taken before planned day of discharge:

- If the ECG is normal, the patient may be discharged safely but counselled regarding warning signs of arrhythmias such as palpitation, presyncope and syncope as new-onset conduction disturbances may occur during a recovery phase. 


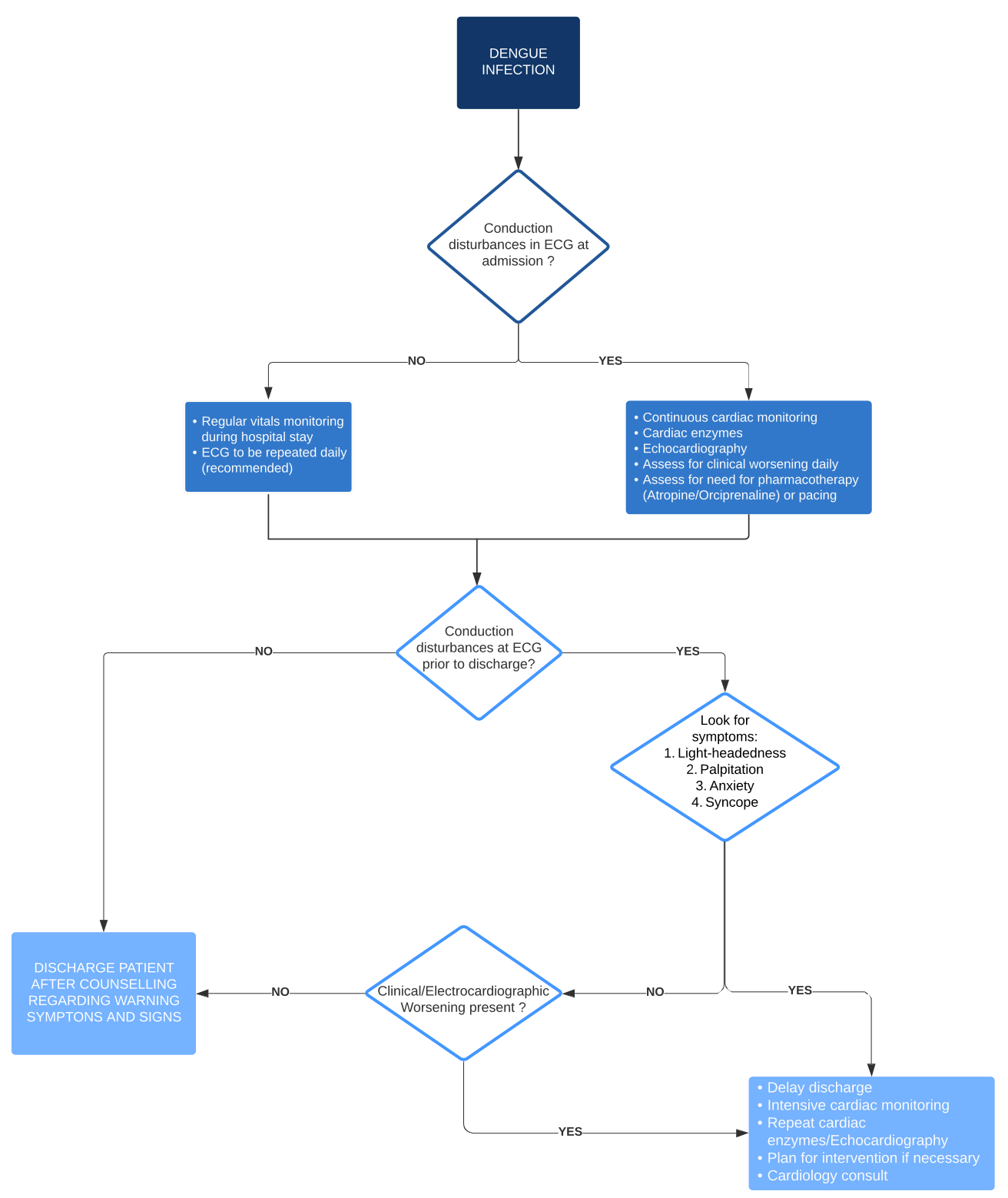

Figure 2 Algorithm of evaluation and management of conduction abnormalities in dengue fever.

- If ECG is abnormal, then one should ask for symptoms. If the patient is symptomatic, it is advisable to delay discharge, initiate intensive cardiac monitoring and plan for an intervention to be provided if necessary. If the patient is asymptomatic, then the trend of conduction abnormality should be assessed -

- New-onset: May discharge with advice on warning signs and quick hospital visit if any warning signs present. It may not be feasible to keep the patient in hospital until ECG becomes normal, as it may take weeks or months for a resolution to occur.

- Improving trend: May discharge.
- Worsening trend: To keep in hospital for further monitoring and intervention as required.

\section{Conclusion}

The spectrum of conduction abnormalities in dengue fever is broad, ranging from relative bradycardia to lifethreatening arrhythmias. Most electrocardiographic changes are transient and resolve by three weeks without requiring any intervention. A thorough evaluation is warranted in symptomatic patients as well as non-resolving /worsening rhythm disturbances. Such patients could benefit from current modalities of therapy. It is vital for 
a physician to be aware regarding electrocardiographic changes and their management in dengue patients for making better informed decisions for their patients.

\section{Author Contributions}

All authors made a significant contribution to the work reported, whether that is in the conception, study design, execution, acquisition of data, analysis and interpretation, or in all these areas; took part in drafting, revising or critically reviewing the article; gave final approval of the version to be published; have agreed on the journal to which the article has been submitted; and agree to be accountable for all aspects of the work.

\section{Disclosure}

The authors declare no conflicts of interest in this work.

\section{References}

1. Weerakoon KG, Kularatne SA, Edussuriya DH, et al. Histopathological diagnosis of myocarditis in a dengue outbreak in Sri Lanka, 2009. BMC Res Notes. 2011;4(1):268. doi:10.1186/17560500-4-268

2. World Health Organization. Dengue Haemorrhagic Fever: Diagnosis, Treatment,Prevention and Control. Vol. 1. Geneva; 1997:24-30.

3. Poornima H, John J. Cardiac manifestations in dengue patients in a rural tertiary care centre in coastal Kerala. Int J Innov Res Med Sci. 2019;4(4). doi:10.23958/ijirms/vol04-i04/628

4. Shah C, Vijayaraghavan G, Kartha CC. Spectrum of cardiac involvement in patients with dengue fever. Int J Cardiol. 2021;324:180-185. doi:10.1016/j.ijcard.2020.09.034

5. Halstead SB. Pathogenesis of dengue: challenges to molecular biology. Sci New Ser. 1988;239(4839):476-481.

6. Kurane I. Dengue hemorrhagic fever with special emphasis on immunopathogenesis. Comp Immunol Microbiol Infect Dis. 2007;30 (5-6):329-340. doi:10.1016/j.cimid.2007.05.010

7. Perera R, Kuhn RJ. Structural proteomics of dengue virus. Curr Opin Microbiol. 2008;11(4):369-377. doi:10.1016/j.mib.2008.06.004

8. Restrepo BN, Isaza DM, Salazar CL, Ramírez R, Ospina M, Alvarez LG. Serum levels of interleukin-6, tumor necrosis factor-alpha and interferon-gamma in infants with and without dengue. Rev Soc Bras Med Trop. 2008;41(1):6-10. doi:10.1590/ S0037-86822008000100002

9. Hober D, Delannoy A-S, Benyoucef S, De Groote D, Wattré P. High levels of sTNFR p 75 and TNF $\alpha$ in dengue-infected patients. Microbiol Immunol. 1996;40(8):569-573. doi:10.1111/j.1348-0421.1996.tb01110.x

10. Chen R-F, Yang KD, Wang L, Liu J-W, Chiu C-C, Cheng J-T. Different clinical and laboratory manifestations between dengue haemorrhagic fever and dengue fever with bleeding tendency. Trans $R$ Soc Trop Med Hyg. 2007;101(11):1106-1113. doi:10.1016/j. trstmh.2007.06.019

11. Chen R-F, Liu J-W, Yeh W-T, et al. Altered T helper 1 reaction but not increase of virus load in patients with dengue hemorrhagic fever. FEMS Immunol Med Microbiol. 2005;44(1):43-50. doi:10.1016/j. femsim.2004.11.012
12. Singhi S, Kissoon N, Bansal A. Dengue and dengue hemorrhagic fever: management issues in an intensive care unit. J Pediatr (Rio J). 2007;83(7):22-35. doi:10.2223/JPED.1622

13. de Araújo JMG, Schatzmayr HG, de Filippis AMB, et al. A retrospective survey of dengue virus infection in fatal cases from an epidemic in Brazil. J Virol Methods. 2009;155(1):34-38. doi:10.1016/j.jviromet.2008.09.023

14. da Lima MRQ, Nogueira RMR, Schatzmayr HG, de Filippis AMB, Limonta D, Dos Santos FB. A new approach to dengue fatal cases diagnosis: NS1 antigen capture in tissues. PLoS Negl Trop Dis. 2011;5(5):e1147. doi:10.1371/journal.pntd.0001147

15. Salgado DM, Eltit JM, Mansfield K, et al. Heart and skeletal muscle are targets of dengue virus infection. Pediatr Infect Dis J. 2010;29 (3):238-242. doi:10.1097/INF.0b013e3181bc3c5b

16. Krishna A, Kumar S, Kumar A, Prasad U. ECG manifestation in dengue fever. Int J Health Clin Res. 2021;4(1):292-297.

17. Tisoncik JR, Korth MJ, Simmons CP, Farrar J, Martin TR, Katze MG. Into the eye of the cytokine storm. Microbiol Mol Biol Rev. 2012;76(1):16-32. doi:10.1128/MMBR.05015-11

18. Virk HUH, Inayat F, Rahman ZU. Complete heart block in association with dengue hemorrhagic fever. Korean Circ J. 2016;46(6):866. doi:10.4070/kcj.2016.46.6.866

19. Dhariwal AK. High degree atrioventricular block with ventricular asystole in a case of dengue fever. Indian Heart J. 2016;4:S194-7.

20. Wali JP, Biswas A, Chandra S, et al. Cardiac involvement in dengue haemorrhagic fever. Int J Cardiol. 1998;64(1):31-36. doi:10.1016/ S0167-5273(98)00008-4

21. Papalkar P, Sarode R, Acharya S, Kumar S. Cardiac manifestations in dengue. Indian J Med Spec. 2019;10(1):30. doi:10.4103/INJMS. INJMS $34 \quad 18$

22. Datta G, Mitra PA. Study on cardiac manifestations of dengue fever. J Assoc Physicians India. 2019;67(7):14-16.

23. Kumar S, Yadav RK. To study cardiac manifestations in patients presenting with dengue infection and to find out the correlation of cardiac manifestations to warning signs of dengue. Int $J$ Adv Med. 2017;4(2):323. doi:10.18203/2349-3933.ijam20171003

24. Arora M, Patil RS. Cardiac manifestation in dengue fever. $J$ Assoc Physicians India. 2016;64(7):40.

25. Yacoub S, Griffiths A, Hong Chau TT, et al. Cardiac function in Vietnamese patients with different dengue severity grades. Crit Care Med. 2012;40(2):477-483. doi:10.1097/CCM.0b013e318232d966

26. La-orkhun V, Supachokchaiwattana P, Lertsapcharoen P, Khongphatthanayothin A. Spectrum of cardiac rhythm abnormalities and heart rate variability during the convalescent stage of dengue virus infection: a Holter Study. Ann Trop Paediatr. 2011;31 (2):123-128. doi:10.1179/1465328111Y.0000000008

27. Kularatne SAM, Pathirage MMK, Kumarasiri PVR, Gunasena S, Mahindawanse SI. Cardiac complications of a dengue fever outbreak in Sri Lanka, 2005. Trans $R$ Soc Trop Med Hyg. 2007;101 (8):804-808. doi:10.1016/j.trstmh.2007.02.021

28. Taksande A, Suwarnakar K. Spontaneous resolution of junctional rhythm in a child with dengue fever. J Prev Infect Control. 2016;2 (1). doi:10.21767/2471-9668.100010

29. Tarique S, Murtaza G, Asif S, Qureshi IH. ECG manifestations in dengue infection. Ann King Edward Med Univ. 2013;19(4):282. doi:10.21649/akemu.v19i4.528

30. Singh S, Sreenivasulu P, Sud S, Sasidharan S, Gupta A, Rare A. Case of dengue hemorrhagic fever with myocarditis and intracranial hemorrhage. J Pediatr Neurosci. 2020;15(3):320-321. doi:10.4103/ jpn.JPN_48_20 


\section{Publish your work in this journal}

The International Journal of General Medicine is an international, peer-reviewed open-access journal that focuses on general and internal medicine, pathogenesis, epidemiology, diagnosis, monitoring and treatment protocols. The journal is characterized by the rapid reporting of reviews, original research and clinical studies across all disease areas. The manuscript management system is completely online and includes a very quick and fair peer-review system, which is all easy to use. Visit http://www.dovepress.com/ testimonials.php to read real quotes from published authors. 